\title{
PERAN JURNALISME PROFETIK MENGHADAPI HOAX ${ }^{1}$
}

\author{
Oleh: Dian Muhtadiah \\ Dosen Jurusan Ilmu Komunikasi \\ Fakultas Ilmu Sosial dan Ilmu Politik \\ Universitas Muhammadiyah Makassar \\ E-mail: dianmuhtadiah@yahoo.com
}

\begin{abstract}
Terror" hoax or information in the form of text, images, or video lying or twisting is considered to be so massive terrorizing public spaces in the network (online) in Indonesia. Start from image or text links in online social networks, such as Facebook, Twitter, Instagram to chain messages in the Whats-app group. Internet users who are not on guard with ghost terror hoax easily spread it to their colleagues in the online space so as to bring the effect of a growing snowball. The prophetic journalism offered in the Islamic press offers solutions to minimize the terror of the hoax.
\end{abstract}

Key words: Hoax, journalism, prophetic journalism, social media

\footnotetext{
${ }^{1}$ Dian Muhtadiah Hamna, Staf Pengajar Prodi Ilmu Komunikasi Fisipol Universitas Muhammadiyah Makassar ,
} Mantan Jurnalis dan Editor Harian Fajar (Jawa Pos Group), anggota AJI Makassar. 


\section{A. Latar Belakang}

Kebebasan pers dinilai tidak pernah mengalami ancaman sebesar sekarang. Saat ini, terjadi fenomena kebenaran diambil alih oleh berita-berita bohong. Indeks kebebasan pers AS dan Inggris turun, sedangkan Indonesia menempati peringkat ke-124 dari 180 negara. Organisasi Wartawan Lintas Batas (RSF) mengingatkan adanya ancaman terhadap kebebasan pers akibat berita-berita bohong.

Ketua Satuan Tugas Multimedia Divisi Humas Mabes Polri Komisaris Besar Sulistyo Pudjo mengutip hasil penelitian pakar teknologi informasi Pratama Persada menyebutkan, informasi hoax sudah mencakup 60 persen dari konten media sosial di Indonesia. Informasi palsu, bohong atau pelintiran yang dimaksud terdiri dari gradasi kandungan informasi bohong yang bervariasi, baik 100 persen, 60 persen, atau 50 persen. $^{2}$

Dikhawatirkan, informasi tersebut mengarah pada propaganda terorisme. Hal ini ditunjukkan dengan banyaknya kelompok teroris yang telah memiliki ratusan bahkan ribuan situs dengan berbagai bahasa sebagai instrumen propagandanya. Dalam penelitian yang dilakukan oleh Gabriel Weimann, perkembangan situs yang dimiliki kelompok teroris dari tahun ke tahun selalu meningkat. Pada 1998, kelompok teroris hanya memiliki 12 situs, kemudian meningkat pada 2003 dengan 2.650 situs. Catatan terakhir, pada 2014 kelompok teroris telah teridentifikasi mengelola lebih dari 9.800 situs. $^{3}$

Informasi palsu yang disebarkan di ruang digital cukup beragam. Mulai bidang politik, kesehatan, sosial ataupun keamanan dan ketertiban. Hal ini bisa menimbulkan kebingungan atau bahkan menyesatkan di kalangan masyarakat.

Dalam perspektif konstruktivis, realitas sosial tidak terlepas dari konstruksi pemikiran. Dengan begitu, informasi palsu yang terus menerus memapar masyarakat lama-lama akan dianggap

\footnotetext{
${ }^{2}$ Menangkal “Hantu” Ruang Daring, Kompas, ed. Rabu, 18 Januari 2017

${ }^{3}$ SB, Agus. 2016. Deradikalisasi Dunia Maya; Mencegah Simbiosis Terorisme dan Media. Jakarta: Daulat Press, h.69
} 
sebagai realitas. Dampak lebih jauh, muncul pula kekhawatiran informasi hoax bisa mengganggu kohesi sosial bangsa Indonesia.

Negara yang fondasi demokrasinya lebih maju dari Indonesia juga lebih dahulu mengalami hal ini. Pemilihan Presiden Amerika Serikat akhir 2016 kerap menjadi rujukan soal dampak negatif informasi palsu dan penuh kebohongan. Kekalahan calon presiden dari Partai Demokrat, Hillary Clinton disebut-sebut dampak dari informasi palsu yang menyebar luas di media sosial menjelang pemungutan suara pada November 2016. Implikasinya, hingga kurang sepekan sebelum pelantikan Presiden terpilih AS, Donald Trump, rakyat AS masih terpecah. Perpecahan itu juga diperuncing perang kata-kata antara pendukung Trump dan mereka yang mengkritik.

Relasi antara informasi palsu dan keterpecahan politik juga bisa ditemui di Indonesia. Politisi Partai Demokrat yang juga pegiat media sosial, Roy Suryo menuturkan, ada sumbangsih faktor keterbelahan masyarakat dalam penyebaran informasi hoax di dunia maya. Hal ini berawal dari pemilihan Gubernur DKI Jakarta tahun 2012, berlanjut pada Pilpres 2014. Menurut dia, ada keterbelahan masyarakat yang pro dan kontra terhadap rezim yang berkuasa. Tiap pihak juga memiliki "pasukan" pendukung di dunia maya. Pemilihan umum 2019 belum berlangsung tetapi embrionya sudah muncul pada Pilkada DKI Jakarta 2017.

\section{B. Berita dalam Pusaran Hoax}

Kabar bohong bukanlah masalah yang dihadapi oleh Indonesia saja. Hampir berdampingan dengan banjir informasi yang dihadirkan oleh internet, kabar bohong pun menjadi masalah yang dijumpai di negara lain. Gempa bumi yang terjadi di Fukushima, Jepang, tahun 2011 lalu juga memunculkan hoax bahwa obat kumur yang mengandung yodium dan rumput laut mencegah kerusakan akibat radiasi.

Peerapon Anutarasoat dari Thai News Agency juga terlibat dalam perang melawan kabar bohong menggunakan layanan perpesanan dan kanal di layanan video Youtube. Melalui kanal bernama "Sure and Share", dia menyisir satu demi satu kabar bohong yang marak diperbincangkan di layanan perpesanan Line untuk kemudian dicari penjelasannya. Dengan informasi yang berhasil dikumpulkan, Peerapon memverifikasi ke sumber yang kompeten, baik itu perusahaan maupun ahli yang terkait. Pemilihan format video di Youtube dilakukan agar bisa jadi referensi apabila suatu hari hoax serupa kembali mengemuka. 
Hoax umumnya disebar menggunakan teks atau gambar yang menggiring kesimpulan pembaca untuk meyakini sesuatu. Sebuah peristiwa yang benar-benar terjadi sering kali juga ditunggangi oleh kabar bohong melalui penggunaan gambar atau video yang konteksnya tidak terkait sama sekali. Atau sebuah rekaman peristiwa yang sudah lama terjadi dibungkus oleh narasi seolah baru saja berlangsung.

Motivasi menyebarkan hoax pun beragam, mulai dari sekadar iseng demi lelucon semata hingga menebarkan kerisauan atau memprovokasi demi agenda politik. Beredar melalui media sosial maupun layanan perpesanan yang terpasang sebagai aplikasi di gawai, hoax pun tidak bisa dipisahkan dari mayoritas masyarakat Indonesia yang sudah akrab dengan perangkat seperti ponsel pintar atau sabak elektronik.

Bahaya hoax bisa merenggut nyawa seseorang. Misalnya kasus orang meninggal setelah serangan stroke karena terlambat dibawa ke rumah sakit gara-gara ada yang mengikuti instruksi yang didapatkan dari media sosial. Bukannya segera membawa ke rumah sakit, teman-temannya justru mengikuti metode yang dibaca dari media sosial berupa tusukan-tusukan jarum di ujung jari. Dalam pesan berantai yang pernah marak, metode ini diklaim bisa membantu menurunkan tekanan darah sehingga bisa meredakan atau menyelamatkan rekan yang terkena stroke. Bukannya sembuh, nyawanya justru tidak bisa diselamatkan karena terlambat ditangani.

Kasus lainnya, meninggalnya Maman Budiman di Pontianak akibat dikeroyok warga karena disangka penculik anak gara-gara kabar yang beredar di masyarakat pada awal tahun 2017. Perusakan wihara di Tanjung Balai Sumatera Utara pada Juli 2016 juga disebabkan provokasi di media sosial. Penelitian Swati Bute dalam The Role of Social Media in Mobilizing People for Riots and Revolutions, menggambarkan bagaimana kerusuhan di Assam (2012) dan Muzaffarpur (2013) dipicu informasi palsu di media sosial. ${ }^{4}$

Hoax mengenai investasi bodong juga berhasil menggaet korban di Wonosobo. Ratusan orang terbujuk berinvestasi dalam bisnis jual pulsa. Saat roda operasi mulai macet dan akhirnya berhenti, kerugian yang muncul ditaksir mencapai ratusan miliar rupiah. Penipuan yang

\footnotetext{
${ }^{4}$ Ujaran Kebencian yang Membelah, Kompas, ed. Senin, 28 November 2016
} 
memanfaatkan kabar bohong di media sosial dan konvensional menimbulkan gangguan ekonomi di kota kecil tersebut.

Lingkaran setan hoax juga menimpa kalangan wartawan. Ironisnya, mayoritas wartawan masa kini ternyata memilih jalan paling mudah untuk menulis, menemukan ide berita, sekaligus memverifikasi sebuah fakta hanya dengan mengandalkan sumber media sosial. Indonesian Journalist Technographics Report 2012-2013 dengan sampel 362 jurnalis merilis sosial media bahkan menjadi rujukan bagi jurnalis memeroleh ide berita sebanyak 85 persen. ${ }^{5}$

Apa penyebab masifnya hoax? Inisiator Komunitas Masyarakat Indonesia Anti Hoax, Septiaji Eko Nugroho menilai, rendahnya kesadaran literasi menjadi salah satu faktor pendorong masifnya peredaran kabar bohong atau hoax. Dengan budaya baca yang rendah, masyarakat menelan informasi secara instan tanpa berupaya mencerna utuh. Bangsa Indonesia, bagi dia, adalah bukan bangsa pembaca tetapi bangsa ngerumpi. Informasi yang diterima langsung diyakini sebagai sebuah kebenaran, lalu berupaya membagi informasi tersebut kepada orang lain. Hal ini relevan dengan catatan UNESCO (Organisasi Pendidikan, Ilmu Pengetahuan, dan Kebudayaan Perserikatan Bangsa-bangsa). Indeks membaca bangsa Indonesia menurut UNESCO (2012) hanya 0,001. Artinya, di antara 1.000 orang, hanya satu orang yang membaca secara serius. Demikian pula catatan survey Most Literated Nation in The World (2015) menempatkan Indonesia pada peringkat ke-60 dari 61 negara. Namun, dosen Filsafat Universitas Indonesia, Tommy F Awuy meluruskan bahwa penyebaran berita bohong kadang tidak selalu relevan dengan tingkat literasi. Sejumlah grup media sosial tertentu juga dihuni oleh orang dengan tingkat literasi yang memadai. ${ }^{6}$

Lalu dimana posisi berita dalam hoax, bisakah hoax disebut sebagai berita? Pertanyaan ini jamak terdengar. Dalam Pasal 3 Kode Etik Jurnalistik berbunyi: Wartawan Indonesia selalu menguji informasi, memberitakan secara berimbang, tidak mencampurkan fakta dan opini yang menghakimi, serta menerapkan asas praduga tak bersalah. Pasal ini menafsirkan bahwa menguji informasi berarti melakukan check and recheck tentang

\footnotetext{
${ }^{5}$ Adi Prasetyo, Stanley. Kode Etik dan Persoalan Pers. Makalah disampaikan dalam Uji Kompetensi Jurnalis (UKJ) Aliansi Jurnalis Independen (AJI) Makassar, Hotel Remcy, 21 Juli 2017

${ }^{6}$ Literasi Rendah Ladang “Hoax”, Kompas, ed. Selasa, 7 Februari 2017
} 
kebenaran informasi itu, berimbang adalah memberikan ruang atau waktu pemberitaan kepada masing-masing pihak secara proporsional, opini yang menghakimi adalah pendapat pribadi wartawan. Hal ini berbeda dengan opini interpretatif, yaitu pendapat yang berupa interpretasi wartawan atas fakta serta asas praduga tak bersalah adalah prinsip tidak menghakimi seseorang. ${ }^{7}$ Sehingga sebuah berita sebelum dipublikasikan oleh wartawan profesional harus mengikuti prosedural kaidah jurnalistik ini. Ini berbeda dengan hoax yang bisa dilakukan oleh siapa saja dengan konten apa saja tanpa melalui prosedural etika jurnalistik tersebut.

Pengertian hoax atau pemberitaan palsu sendiri adalah usaha untuk menipu atau mengakali pembaca/pendengarnya untuk mempercayai sesuatu, padahal sang pencipta berita palsu tersebut tahu bahwa berita tersebut adalah palsu. Salah satu contoh pemberitaan palsu yang paling umum adalah mengklaim sesuatu barang atau kejadian dengan suatu sebutan yang berbeda dengan barang/kejadian sejatinya. Suatu pemberitaan palsu berbeda dengan misalnya pertunjukan sulap; dalam pemberitaan palsu, pendengar/penonton tidak sadar sedang dibohongi, sedangkan pada suatu pertunjukan sulap, penonton justru mengharapkan supaya ditipu. ${ }^{8}$

Filsuf Inggris, Robets Nares (1753-1829) mengatakan bahwa kata tipuan diciptakan pada akhir abad ke-18 sebagai kontraksi kata kerja yang memusatkan perhatian, yang berarti "menipu", "memaksakan pada" atau "sering dikelirukan dengan minuman keras yang dikeringkan".

Robert Nares mendefinisikan kata tipuan sebagai "cheat", yang berasal dari buku Thomas Ady's 1656 "A Candle in the Dark" atau sebuah risalah tentang sifat penyihir dan sihir. Istilah tipuan kadang-kadang digunakan mengacu pada legenda dan rumor kota, namun folklorist Jan Harold Brunvand berpendapat bahwa kebanyakan dari mereka tidak memiliki bukti penciptaan palsu yang disengaja dan diwariskan dengan itikad baik oleh orang-orang percaya atau sebagai lelucon, jadi istilahnya seharusnya digunakan hanya untuk orang-orang dengan kemungkinan usaha sadar untuk menipu. Adapun istilah dan lelucon praktis yang terkait erat, Brunvand menyatakan bahwa walaupun ada kasus di mana mereka saling tumpang tindih, tipuan cenderung menunjukkan "rekayasa yang relatif rumit dan berskala besar" dan mencakup tipu daya yang

\footnotetext{
${ }^{7} \mathrm{http} / /$ www.lpds.or.id/index.php?option=com_content\&view=article\&id=40:kode-etikjurnalistik\&catid=30:kode-etik-jurnalistik\&Itemid=32, diakses Senin, 21 Agustus 2017. ${ }^{8}$ (https://id.wikipedia.org/wiki/Pemberitaan_palsu), akses Senin, 21 Agustus 2017
} 
melampaui sekadar bermain-main dan "menyebabkan kehilangan materi atau merugikan korban".

Menurut Profesor Lynda Walsh dari University of Nevada, Reno, beberapa tipuanseperti Great Stock Exchange Fraud of 1814, yang dicap sebagai tipuan oleh komentator kontemporer - bersifat finansial, dan pembohong yang sukses - seperti PT Barnum sering memperoleh keuntungan atau ketenaran melalui rekayasa mereka, jadi perbedaan antara tipuan dan penipuan belum tentu jelas. Alex Boese, pencipta Museum Hoax, menyatakan bahwa satusatunya perbedaan di antara mereka adalah reaksi publik, karena kecurangan dapat diklasifikasikan sebagai tipuan ketika metode perolehan keuntungan finansial menciptakan dampak publik yang luas atau menangkap imajinasi massa.

Salah satu tipuan media yang paling awal direkam adalah almanak palsu yang diterbitkan oleh Jonathan Swift dengan nama samaran dari Ishak Bickerstaff pada tahun 1708. Swift meramalkan kematian John Partridge, salah satu astrolog terkemuka di Inggris saat itu di almanak dan kemudian mengeluarkan sebuah elegan pada hari Partridge seharusnya meninggal. Akibatnya, reputasi Partridge rusak dan almanak astrologinya tidak dipublikasikan dalam enam tahun ke depan. ${ }^{9}$

Dalam Alquran telah jelas diterangkan bahwa berita bohong adalah modalnya orang munafik untuk merealisasikan niat kotor mereka, sebagaimana yang terkandung dalam QS AlAhzaab:33/60-61;

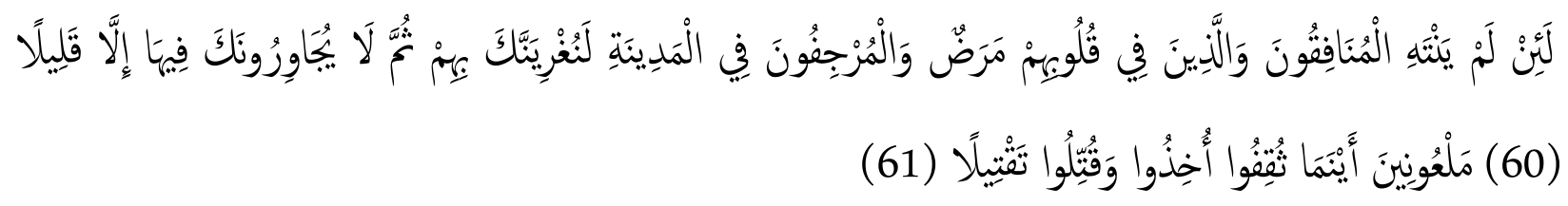

Terjemahannya:

"Sesungguhnya jika tidak berhenti orang-orang munafik, orang- orang yang berpenyakit dalam hatinya dan orang-orang yang menyebarkan kabar bohong di Madinah (dari menyakitimu), niscaya Kami perintahkan kamu (untuk memerangi)

\footnotetext{
${ }^{9}$ https://en.wikipedia.org/wiki/Hoax, diakses Senin, 21 Agustus 2017
} 
mereka, kemudian mereka tidak menjadi tetanggamu (di Madinah) melainkan dalam waktu yang sebentar, dalam keadaan terlaknat dimana saja mereka dijumpai, mereka ditangkap dan dibunuh tanpa ampun". ${ }^{10}$

Para ulama bersepakat akan batilnya perbuatan membuat berita bohong. Tidak ada ikhtilaf (perbedaan pendapat) mengenai hal itu. Akan tetapi, bagaimana hukumnya bagi yang menyebarkan? Bagaimana bila sebenarnya niatnya baik, agar orang tersentuh hidayah, supaya orang tergerak ukhuwah? Allah berfirman dalam QS al-Isra':17/36;

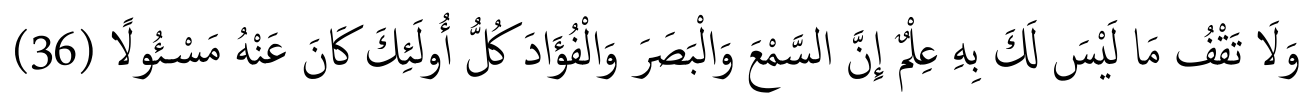

Terjemahannya:

"Dan janganlah kamu mengikuti apa yang kamu tidak mempunyai pengetahuan tentangnya.Sesungguhnya pendengaran, penglihatan dan hati, semuanya itu akan diminta pertanggungan jawabnya". ${ }^{11}$

Ayat diatas menjelaskan bahwa, janganlah kita mengikuti sesuatu yang belum diketahui kebenarannya, baik itu berupa berita yang muncul maupun riwayat tertentu, berupa interpretasi terhadap sebuah fenomena atau analisis terhadap sebuah kejadian, atau berupa hukum syar'i atau masalah keyakinan. Sikap klarifikasi dalam menerima setiap berita, setiap fenomena, dan setiap gerakan sebelum memutuskan tindakan lebih lanjut adalah seruan Alquran dan sistem metodologis Islam yang sangat akurat. ${ }^{12}$

\section{Miliki Sensor Diri, Verifikasi Informasi}

Presiden RI, Joko Widodo dalam puncak Hari Pers Nasional di Lapangan Tantui Ambon, Kamis, 9 Februari 2017 dalam sambutannya mengatakan, gelombang hoax yang terjadi justru akan membuat Indonesia lebih dewasa. Presiden melihat dengan digitalisasi yang terjadi, cenderung membuat semua orang menjadi produsen berita. Setiap saat media sosial selalu kebanjiran berita. Dengan demikian, ada berita yang objektif tetapi ada pula hoax atau kabar

\footnotetext{
${ }^{10}$ Alquran dan Terjemahan, 2011. Depok: Sabiq, h. 426

${ }^{11}$ Ibid, h. 285

${ }^{12}$ Ratnasari. 2017. Pengaruh Informasi Hoax Terhadap Perilaku Mahasiswa Fakultas Dakwah dan Komunikasi (Studi Kasus Jurusan Jurnalistik UIN Alauddin Makassar). Makassar: UIN
} Alauddin, h.25 
bohong yang menggangu. Oleh karena itu, Presiden meminta semua pihak bekerja sama menghadapi hoax. Terutama media arus utama harus meluruskan, tidak larut dalam membuat isu yang belum terverifikasi. Media arus utama tidak boleh luntur dalam menerapkan kode etik jurnalistik (KEJ). ${ }^{13}$

Ketua Umum Persatuan Wartawan Indonesia (PWI), Margiono mengatakan, pers sendiri membangun jaringan wartawan anti-hoax yang bertujuan melawan hoax yang banyak beredar di kalangan masyarakat. Informasi yang benar harus didapatkan oleh masyarakat. Dalam beberapa kenyataan, ada beberapa berita yang selama ini dianggap hoax namun pada kenyataannya itu adalah berita yang benar. Beberapa berita yang selama ini disebutkan sebagai berita palsu namun kenyataannya memang seperti itu. Misalnya, masuknya ratusan tenaga kerja asing secara illegal ternyata kenyataannya seperti itu.

Posisi media massa pun masih kuat dalam keseharian publik. Dalam jajak pendapat Kompas yang dilaksanakan pada 1-3 Februari 2017, delapan dari 10 responden (84 persen) masih menjadikan media massa yang memproduksi karya jurnalistik sebagai sumber informasi yang paling sering digunakan. Hanya sekitar 15 persen yang memilih media sosial. Komposisi yang tidak jauh berbeda juga terlihat ketika responden diminta memilih media mana yang paling dipercayai.

Dalam soal kepercayaan, koran cetak menonjol di antara media lain. Hanya 6,4 persen responden yang menjadikan media cetak ini sebagai sumber informasi yang paling sering dipakai, tetapi terkait kepercayaan akan kebenaran berita yang disajikan angkanya bertambah dua kali lipat lebih (14,2 persen). Sebaliknya, media sosial termasuk grup percakapan seperti Whats-App, justru tertinggi penyusutannya, dari 15 persen menjadi 8,9 persen. ${ }^{14}$ Namun, perubahan lanskap bermedia tersebut perlu diantisipasi seiring kian besarnya penetrasi internet di masyarakat. Data Asosiasi Penyelenggara Jasa Internet Indonesia (APJII) per November 2016 melaporkan bahwa 132,7 juta orang menggunakan internet dengan penetrasi mencapai 51,8

${ }^{13}$ Pers Anti-Hoax, Harian Fajar, ed. Jumat, 10 Februari 2017

${ }^{14}$ Menggugah Pers Hadapi Badai Informasi, Kompas, ed. Senin, 6 Februari 2017 
persen dari total penduduk. Kementerian Komunikasi dan Informatika menyebut, ada 700.000 hingga 800.000 situs yang berisi konten negatif, seperti pornografi, penipuan, berita-berita bohong dan radikalisme.

Dalam kondisi dunia maya seperti itu, hasil jajak pendapat menyebutkan ada 41,6 responden yang mengaku tidak bisa membedakan mana yang termasuk media massa resmi dan terikat kode etik jurnalistik dengan media abal-abal yang hanya menyebarkan berita sensasional, bohong dan provokatif. Semakin rendah pendidikan, semakin sulit bagi mereka memilah kedua media tersebut.

Lalu solusi apa yang bisa digunakan untuk keluar dari teror "hantu hoax" ? Pemerintah Federal Jerman sejak tahun 2016 sudah mendorong penyedia platform media sosial untuk menurunkan informasi bohong dalam waktu 24 jam. Menjelang pemilihan umum federal 2017, Pemerintah Jerman bersikap lebih keras dengan membahas aturan untuk memberi denda pemilik platform yang tidak menurunkan informasi palsu dalam kurun waktu 24 jam. Hal ini tidak terlepas dari kekhawatiran Pemerintah Jerman bahwa informasi palsu akan digunakan partai sayap kanan populis yang ultranasionalis untuk merebut suara. Facebook merespons dengan komitmen untuk bekerja sama dengan organisasi di Jerman, Corrective, sebagai partner dalam pemeriksaan fakta guna menanggulangi informasi palsu.

Staf Ahli Bidang Hukum Kementerian Komunikasi dan Informatika, Henri Subiakto mengatakan pemerintah Indonesia juga sudah mengirim surat kepada penyedia platform bisa bekerja sama untuk mengatasi hoax tersebut. Sementara, Peneliti Lembaga Studi Pers dan Pembangunan, Ignatius Haryanto menekankan pentingnya pendidikan literasi bagi masyarakat. Setiap individu perlu memiliki kemampuan untuk menyaring sebelum sharing (membagikan) konten daring. Sebab, informasi palsu merupakan "racun” bagi demokrasi Indonesia.

Verifikasi informasi atau sensor diri bisa dilakukan setiap orang dalam batas tertentu. Syaratnya adalah ketekunan, ketelitian dan skeptis terhadap setiap informasi yang diterima. Beberapa perangkat yang tersedia gratis untuk dipergunakan bisa dipakai untuk memverifikasi sebuah foto atau video. Beberapa aspek yang perlu diperhatikan adalah lokasi dan waktu pengambilan. Ketelitian wajib dimiliki karena bisa mencari petunjuk visual untuk memastikan 
sebuah gambar memang diambil dari lokasi yang diklaim. Misalnya dari rambu jalan, papan iklan, hingga arsitektur bangunan.

Google memiliki layanan yang bisa dimanfaatkan, seperti Google Images untuk mencari gambar yang mirip, atau Google Maps untuk mencari lokasi berdasarkan petunjuk visual seperti menara gedung. Layanan komputasi Wolfram Alpha adalah layanan yang paling jamak digunakan untuk mencocokkan waktu kejadian melalui pertanyaan saintifik. Basis data yang dimiliki bisa menjadi jawaban akurat dari pertanyaan seperti kondisi cuaca.

Perusahaan internet Google yang hingga kini masih mengumpulkan informasi untuk dipakai para penggunanya juga berkepentingan dengan pemberantasan kabar bohong. News Lab adalah salah satu upaya untuk meningkatkan kapasitas jurnalis dalam memanfaatkan teknologi dalam membongkar kabar bohong di internet. News Lab Asia Pasific Lead, Irene Jay Liu mengatakan peningkatan kapasitas bisa berfaedah dalam hal membangun kredibilitas media massa dalam menjadi referensi pengguna internet yang mencari kepastian. Teknologi baru seperti virtual reality bisa digunakan untuk menyajikan reportase yang lebih memikat. ${ }^{15}$

Dari lingkup keluarga, pencegahan maraknya hoax bukan mustahil dilakukan. Menteri Pemberdayaan Perempuan dan Perlindungan Anak, Yohana Yembise mengimbau para ibu dan perempuan agar ikut berperan mencegah beredarnya berita-berita palsu yang kini marak di media sosial. Diharapkan ibu memberikan pemahaman kepada anak-anak jika menerima informasi lewat media sosial yang belum pasti kebenarannya dan tidak jelas sumbernya.

Direktur Eksekutif Pusat Studi Pancasila Universitas Pancasila, Yudi Latif juga meminta masyarakat memperkuat budaya membaca dan menulis secara kritis untuk melawan hoax. Saat menerima informasi, masyarakat malas untuk membaca secara utuh, menyaring, memilah, mengendapkan, mengecek, apalagi menggugat keakuratan dan kebenarannya. Namun di sisi lain, mereka gagal menahan hasrat atau tergesa-gesa menyebarkan informasi secara luas melalui media sosial dengan harapan dianggap sebagai yang terdepan. Bahkan, hoax dibuat dengan basis data sehingga terkesan serius dan akademik. Penyebar hoax biasanya amat antusias, bahkan serius menggarap informasi tersebut.

${ }^{15}$ Bersama Menolak Kabar Palsu, Kompas, ed. Selasa, 18 Juli 2017 
Oleh karena itu, pendidikan dapat menjadi tulang punggung pencegahan hoax agar tidak menguasai kehidupan generasi mendatang. Pemerintah mempertimbangkan ada hari khusus membaca buku, majalah dan media berkualitas di sekolah. Selain itu, pelatihan berinternet secara sehat harus menjadi rutinitas di sekolah. ${ }^{16}$

\section{Jurnalisme Profetik, Alternatif Tangkal Hoax Bagi Wartawan}

Penyebaran hoax yang masif kerap menggunakan "jasa” media sosial. Padahal kini jumlah khalayak atau pengguna media sosial, jauh lebih banyak dari pelanggan media massa sehingga terlihat bagaimana kekuatan media sosial di bidang jurnalisme.

Namun, mampukah jurnalisme bertahan di era media sosial? Dimana makin sulit menentukan kebenaran di era banjir informasi? Kembali kita diingatkan mengenai prinsip-prinsip jurnalisme ${ }^{17}$ :

1. Kewajiban pertama jurnalisme adalah pada kebenaran

2. Loyalitas pertama jurnalisme adalah kepada masyarakat

3. Intisari jurnalisme adalah disiplin verifikasi

4. Praktisi jurnalisme harus menjaga independensi terhadap sumber berita

5. Jurnalisme harus menjadi pemantau kekuasaan

6. Jurnalisme harus menyediakan forum kritik maupun dukungan masyarakat

7. Jurnalisme harus berupaya keras untuk membuat hal penting menarik dan relevan

8. Jurnalisme harus menyiarkan berita komprehensif dan proporsional

9. Praktisi jurnalisme harus diperbolehkan mengikuti nurani mereka

Jurnalisme menjadi keniscayaan bagi seorang jurnalis profesional. Dimana etika menjadi panduan saat bekerja. Seorang jurnalis harus memiliki pengetahuan tentang kesadaran akan nilai

${ }^{16}$ Siswa Diajari Bermedsos, Kompas, ed. Rabu, 8 Februari 2017

${ }^{17}$ Kovach, Bill dan Tom Rosenstiel. 2006. Sembilan Elemen Jurnalisme. Jakarta: Yayasan Pantau,h. 6 
baik dan nilai buruk, benar dan salah, tepat dan tidak tepat dalam nuraninya karena hal ini memengaruhi nilai "kebenaran" dari berita yang diproduksinya.

Kebenaran dalam konteks informasi pers yakni memberitakan keadaan sebenarnya. Hal ini berkebalikan dengan hoax yang menyembunyikan kebenaran atau mengada-adakan kebenaran. Dalam jurnalistik, terdapat standar minimum sebagai konsep dari kebenaran dalam "menyampaikan kebenaran". Standar tersebut, Pertama, laporan harus akurat, dengan cara melakukan verifikasi fakta sehingga diperoleh bukti yang valid. Adalah kewajiban reporter untuk menyampaikan kebenaran kepada masyarakat, yang paling mendekati kebenaran yaitu dengan memilih narasumber dengan track-record yang dipercaya.

Kedua, untuk mendukung kebenaran dalam media, jurnalis atau reporter perlu melakukan upaya pencerdasan dengan cara mendorong pemahaman audiensi. Suatu laporan harus berisi sejumlah informasi yang memberikan pemahaman bagi audiens. Seorang jurnalis dituntut untuk bisa memposisikan diri antara membuka semua informasi atau sama sekali tidak menyampaikan informasi tersebut.

Ketiga, jurnalis harus memberikan informasi yang jelas dalam laporan liputannya, laporan yang memiliki sifat fair dan seimbang.

Dalam konteks kebenaran terhadap informasi dan komunikasi yang dibangun pers seringkali terjadi bias. Maka terjadilah apa yang dikatakan ambiguitas dalam laporan pers. Berkaitan dengan hal itu, pernyataan Bill Kovach dan Rosentiel bahwa masyarakat butuh prosedur dan proses guna mendapatkan apa yang disebut dengan kebenaran fungsional.

Menurut pandangan Franz Magnis Suseno, bahwa pers boleh memiliki pelbagai tujuan dan harapan, tetapi tujuan-tujuan dan harapan-harapan itu tidak boleh dikejar dengan menyampingkan kebenaran. Apapun yang disajikan pers harus benar; dan pers harus merasa terlibat terhadap kebenaran. ${ }^{18}$

Sekaitan dengan hal ini, menjunjung kebenaran semakin dapat dilakukan oleh seorang jurnalis muslim jika menerapkan jurnalisme profetik atau jurnalisme kenabian atau prophetic journalism.

\footnotetext{
${ }^{18}$ Ayu Astuti, Sri. 2015. Kebebasan Pers dan Etika Pers; Dalam Perspektif Hukum Islam. Yogyakarta: Genta Publishing, h. 129
} 
Jurnalisme profetik adalah jurnalisme yang mengemban tugas kenabian, yakni menyampaikan risalah yang bermanfaat untuk semua orang berdasar cinta sebagai ibadah kepada Allah dengan cara:

- Mengungkapkan kebenaran (truth)

- Menegakkan keadilan (justice)

- Mendukung terciptanya kesejahteraan (prosperity)

- Menciptakan perdamaian (peace)

- Menjunjung tinggi kemanusiaan universal (universal humanity)

Jurnalisme profetik relevan dengan jurnalisme Islami yakni jurnalisme yang meneladani empat kode etik Nabi Muhammad SAW yang ternyata sesuai dengan fungsi media, yakni shiddiq (menyampaikan, to inform), amanah (mendidik, to educate), tabligh (menghibur, to entertain), dan fathanah (melakukan kontrol sosial, social kontrol). Keempatnya juga bisa diartikan: shiddiq (berdasar kebenaran), tabligh (disampaikan dengan cara mendidik), amanah (dapat dipercaya) dan fathanah (dengan penuh kearifan). ${ }^{19}$

Jurnalistik profetik juga merupakan kegiatan syiar-dakwah Islam yang mengemban misi dakwah dengan berpijak pada "amar makruf nahyi mungkar" baik melalui media cetak maupun media audiovisual. ${ }^{20}$ Lepas dari ada atau tidak jurnalistik-pers Islam yang esensial, urgen untuk digalakkan kehadirannya di tengah badai informasi seperti saat ini.

Jurnalistik profetik dipandang sebagai salah satu bagian dari bentuk kegiatan dakwah, juga dilihat sebagai bagian kegiatan komunikasi. Dari sisi ini kemudian timbul dua suku kata yang mendasar, yaitu dakwah dan komunikasi. Secara etimologi, dakwah yang berasal dari bahasa Arab; da'a, yad'u, da'wan, du'a yang berarti upaya mengajak, menyeru, memanggil, seruan, permohonan dan permintaan.

Secara universal, dakwah dalam pengertian terminologi, mengandung ragam pengertian. Pakar di bidang ilmu dakwah, laiknya pakar ilmu komunikasi, yang member tafsiran beragam tentang apa yang dimaksud dakwah dalam segi operasional kegiatannya. Dalam pada itu, Enjang dan Aliyuddin berpendapat; "perbedaan yang terdapat pada setiap penjelasan para pakar dan

\footnotetext{
${ }^{19}$ Hadi, Parni. 2014. Jurnalisme Profetik; Pergulatan, Teori, Aplikasi. Dompet Dhuafa, h. 113

${ }^{20}$ Muhammad, Firdaus. 2013. Jurnalistik Profetik Kontekstualisasi Dakwah Nabi di Era Multimedia. Makassar: Alauddin University Press , h. 9
} 
cendekia itu, kelihatannya lebih pada aspek orientasi dan penekanan bentuk kegiatannya, bukan pada aspek esensinya". ${ }^{21}$

Maka dalam pendekatan ilmiah dan historis, terminologi dakwah yang diketengahkan dalam uraian ini, adalah pendapat Syekh Ali Mahfud dan Sayyid Qutb yang memberi penegasan tentang hakikat (ontologi) dakwah. Lebih lanjut, Syekh Ali Mahfud berpendapat bahwa dakwah sebagai upaya membangkitkan kesadaran manusia di atas kebaikan dan bimbingan, menyuruh berbuat makruf dan mencegah perbuatan mungkar supaya supaya mereka bisa mendapat kebahagiaan dunia dan akhirat.

Tampaknya jika dibandingkan dengan pengertian dakwah yang diterangkan oleh Syekh Ali Mahfud di atas, oleh Sayyid Qutb menjelaskan pengertian dakwah secara universal, dengan penegasan kalimat “...dakwah adalah mengajak atau mendorong orang untuk masuk ke dalam sabilillah, bukan untuk mengikuti da'i atau bukan pula untuk mengikuti sekelompok orang'. Kendati pun tidak secara eksplisit, pengertian kedua lebih cenderung menekankan suatu proses dakwah (tabligh) atau dalam pandangan sentral disebut proses komunikasi.

Dalam kajian ini, istilah komunikasi atau communication berasal dari bahasa latin, yaitu communicatio yang berarti pemberitahuan atau pertukaran. Kata sifatnya communis, yang bermakna umum atau bersama-sama. Onong Uchjana mengemukakan; komunikasi adalah proses penyampaian pesan oleh seseorang kepada orang lain, dengan tujuan memberi tahu atua untuk mengubah sikap, pendapat, atau perilaku baik langsung secara lisan, maupun tidak langsung melalui media tertentu.

Dakwah demikian halnya komunikasi identik dengan konteks maknanya sebagai komunikasi manusia. Namun, keduanya memiliki dimensi-dimensi dan model-model yang beragam, meliputi seluruh aktivitas komunikasi manusia (human communication) bahkan komunikasi transeden (meta communication).

Namun, dalam kaitannya dengan objek jurnalistik, bahasannya dispesifikkan pada domain komunikasi. Onong Uchjana member pengertian sederhana komunikasi massa yaitu “...komunikasi massa melalui media massa modern”. Sementara, Jalaluddin Rakhmat mengemukakan komunikasi massa, yaitu: “jenis komunikasi yang ditujukan kepada semua khalayak yang tersebar, heterogen, dan anonym melalui media cetak atau elektronik sehingga pesan yang sama dapat diterima secara serentak dan sesaat.

\footnotetext{
${ }^{21}$ Muhammad, Firdaus. Op.cit, h.13
} 
Apabila definisi di atas dijadikan sandaran, maka jurnalistik profetik juga mencakup dimensi komunikasi massa. Lazimnya dalam teori komunikasi massa, misalnya unsur-unsur komunikasi gagasan Harold D Lasswell, kemudian dikonseptualisasikan menjadi; (who) jurnalis muslim, (says what) amar makruf nahyi mungkar, (in which channel) pers Islam, (to whom) khalayak, (with what effect) kultur Islam.

Ikhtisar pengertian jurnalistik profetik adalah dakwah oleh jurnalis muslim, baik melalui tulisan maupun lisan, menggunakan sarana komunikasi massa (cetak maupun elektronik), bertujuan menyampaikan informasi atau berita kepada khalayak (komunikan).

Signifikansi jurnalistik profetik sebagai aspek komunikasi yang bertujuan amar makruf nahyi mungkar dijelaskan dalam Quran surah Ali’ Imran/03: 104:

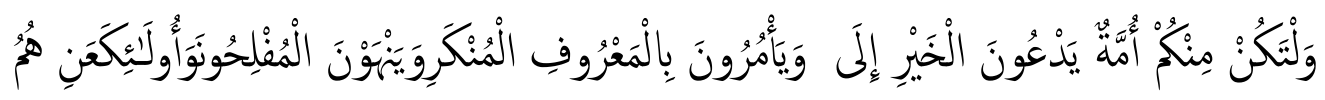

Terjemahannya:

"Dan hendaklah ada di antara kamu segolongan umat yang menyeru kepada kebajikan, menyuruh kepada yang ma'ruf dan mencegah dari yang munkar; merekalah orang-orang yang beruntung"

Inilah yang dimaksud Onong Uchjana dengan fungsi komunikasi, tidak sekadar how to communication works (dassein) tetapi how communication (dassollen dan daswollen) agar terjadi perubahan sikap (attitude), pandangan (opinion), perilaku (behaviour) kepada individu (mikro) kelompok (meso) dan masyarakat (makro) sesuai kandungan ayat tersebut di atas.

Di tengah pesatnya arus informasi sekarang, masyarakat seringkali disuguhi aneka ragam nilai yang tidak hanya membingungkan, tetapi juga berpotensi menyesatkan umat. Allah SWT telah menukilkan bahwa dalam perjalanan sejarah kemanusiaan, selalu muncul orang-orang yang mempergunakan berbagai idiom dan sarana komunikasi yang ada dengan tujuan untuk menyesatkan manusia dan berpaling dari jalan-Nya. (QS. Lukman/31:6)

Fenomena historis itu menuntut pembentukan kelompok-kelompok khusus sebagai "perisai" dari penetrasi informasi yang berpotensi menyesatkan. Kelompok khusus itu juga berperan mengintrodusir nilai-nilai Islam yang sesuai dengan kondisi umat pada waktu dan tempat tertentu. Dalam perspektif jurnalistik, ini sangat strategis dilakukan oleh umat Islam yang memiliki kecakapan teknis untuk menekuni profesi jurnalistik. Fungsi strategisnya tidak hanya berdasarkan realitas kehidupan umat, tetapi juga karena "perintah" agama. 
Banyak ayat dalam Alquran yang jika direnungkan substansi dan kandungannya menjadi rujukan berbagai prinsip dalam proses kerja jurnalistik yang dapat menangkal masifnya hoax. Prinsip-prinsip itu antara lain: ${ }^{22}$

- Prinsip akurat. Modal utama profesi jurnalistik adalah keterpercayaan. Keterpercayaan tumbuh dari sikap objektif dalam melihat dan menangkap nilai peristiwa yang terjadi dan dijadikan sumber informasi dan data aktual produk jurnalistik. Itulah yang disebut akurat. Akurasi infomasi dan data hanya mungkin diperoleh melalui pengecekan yang jujur, teliti dan sungguh-sungguh. Verifikasi informasi "diperintahkan" dalam ajaran Islam. Informasi tanpa verifikasi dalam perspektif Alquran dapat mengakibatkan bencana dalam kehidupan manusia. (QS. al-Hujuraat/49: 6).

- Kedua, prinsip adil. Komunikasi dan penyebaran informasi harus senantiasa dalam batas-batas kewajaran dan kepatutan (fairness). Semua pihak yang berkaitan dengan informasi, berhak menyuguhkan data sesuai perspektifnya masing-masing (berimbang). Informasi yang dilansir media harus selalu komprehensif (cover both sides). Tidak boleh memutarbalikkan fakta, baik disebabkan dorongan hawa nafsu maupun karena ingin menyimpang dari kebenaran. (QS. an-Nisaa/4:35)

- Ketiga, asas praduga tak bersalah. Informasi yang patut menjadi bahan berita tidak boleh bersumber dari rumor. Model pemberitaan yang dilakukan tidak boleh bernada ejekan atau berisi mengolok-olok: siapa pun dan kelompok mana pun. Prasangka buruk juga harus dihindari dalam pemberitaan. Mencari-cari kesalahan orang lain dengan tujuan menjelekjelekkannya adalah fenomena jurnalistik yang dilarang dalam Islam. (QS. al-Hujurat/49: 1112).

- Keempat, menggunakan kata bermakna, santun, lembut dan argumentatif dalam menyampaikan informasi atau berita. Prinsip ini dalam bahasa Alquran disebut bi alhikmah (QS. an-Nahl/16:125). Kata hikmah dalam ayat ini adalah perkataan yang tegas dan benar, yang dapat membedakan antara yang haq dengan bathil. Jurnalis yang memahami alhikmah

- Kelima, menjunjung tinggi kebenaran, kejujuran, dan menghindari informasi dusta. Dalam Bahasa Indonesia, dusta adalah "kabar bohong" atau "perkataan yang tidak

\footnotetext{
${ }^{22}$ Santing, Waspada. 2011. Profesi Jurnalistik Perspektif Hukum Islam. Makassar: Alauddin University Press, h.
} 101 
sesuai yang sebenarnya". Dalam profesi jurnalistik, tidak dibolehkan menggunakan informasi yang bersumber dari kabar bohong untuk bahan berita. Prinsip ini berdasarkan petunjuk dalam Alquran (QS.al-Hajj/22:30). Kata zur dalam ayat ini-secara harfiah artinya "berbohong" dan “kesaksian palsu”. Misalnya, rajul zur (laki-laki pembohong), qaum zur (kaum pembohong). Pengertian tersebut sama dengan makna kaziba dalam QS. Yunus/10: 6. Demikian pula “ancaman” kepada para pendusta sebagaimana dikemukakan Allah SWT dalam QS. alJatsiyah/45:7.

Berbohong, berdusta, dan memberikan kesaksian palsu dampak negatifnya sangat besar. Mungkin itu sebabnya Rasulullah SAW menyetarakan dosa kesaksian palsu dengan dosa menyekutukan Allah SWT. Oleh karena itu, para jurnalis harus melakukan verifikasi yang sangat ketat terhadap setiap data dan informasi yang diperoleh sebelum data dan informasi itu digunakan sebagai bahan berita. Allah SWT memperingatkan bahwa orang yang menyebarkan informasi yang tidak jelas sumbernya akan dimintai pertanggungjawabannya. (QS. al-Israa'/17: 36).

\section{E. Penutup}

Media sosial diciptakan untuk memudahkan masyarakat menembus akses tanpa batas ruang dan waktu. Namun, penggunaan media sosial yang kebablasan justru menjadi bumerang bagi warganet sendiri. Hoax adalah salah satu implikasi negatif penyalahgunaan penyebaran informasi di internet. Ironisnya, masyarakat mudah percaya begitu saja informasi di media sosial tanpa verifikasi atau mengecek kebenaran informasi tersebut. Alasannya, agar tetap terlihat "up date" atau terdepan dalam memeroleh wawasan baru.

Kendati demikian, masih ada harapan meminimalkan pengaruh "lingkaran setan hoax". Etika jurnalisme menjadi kunci bagi wartawan-di tengah upaya bertahan- menjadi garda terdepan dalam penyebaran informasi. Bahkan jurnalisme dalam perspektif Islam, telah menawarkan solusi tersebut lebih dahulu dalam menghadapi hoax. Solusi yang bersumber dari Alquran dan hadis. Mampukah jurnalis menegakkannya? Jawabannya kembali pada hati nurani. (*) 


\section{DAFTAR PUSTAKA}

\section{A. Buku}

Ayu Astuti, Sri. 2015. Kebebasan Pers dan Etika Pers; Dalam Perspektif Hukum Islam. Yogyakarta: Genta Publishing

Alquran dan Terjemahan, 2011. Depok: Sabiq

Hadi, Parni. 2014. Jurnalisme Profetik; Pergulatan, Teori, Aplikasi. Dompet Dhuafa

Kovach, Bill dan Tom Rosenstiel. 2006. Sembilan Elemen Jurnalisme. Jakarta: Yayasan Pantau

Muhammad, Firdaus. 2013. Jurnalistik Profetik Kontekstualisasi Dakwah Nabi di Era

Multimedia. Makassar: Alauddin University Press

Santing, Waspada. 2011. Profesi Jurnalistik Perspektif Hukum Islam. Makassar: Alauddin University Press

SB, Agus. 2016. Deradikalisasi Dunia Maya; Mencegah Simbiosis Terorisme dan Media. Jakarta: Daulat Press

\section{B. Disertasi/Tesis/Skripsi}

Ratnasari. 2017. Pengaruh Informasi Hoax Terhadap Perilaku Mahasiswa Fakultas Dakwah dan Komunikasi (Studi Kasus Jurusan Jurnalistik UIN Alauddin Makassar). Makassar: UIN Alauddin. Skripsi.

\section{Koran}

Ujaran Kebencian yang Membelah, Kompas, ed. Senin, 28 November 2016

Menggugah Pers Hadapi Badai Informasi, Kompas, ed. Senin, 6 Februari 2017

Berita Palsu Mengancam, Kompas, ed. Kamis, 27 April 2017

Menangkal "Hantu” Ruang Daring, Kompas, ed. Rabu, 18 Januari 2017

Literasi Rendah Ladang “Hoax”, Kompas, ed. Selasa, 7 Februari 2017 
Siswa Diajari Bermedsos, Kompas, ed. Rabu, 8 Februari 2017

Pers Anti-Hoax, Harian Fajar, ed. Jumat, 10 Februari 2017

Bersama Menolak Kabar Palsu, Kompas, ed. Selasa, 18 Juli 2017

\section{Internet}

https://id.wikipedia.org/wiki/Pemberitaan_palsu, diakses Senin, 21 Agustus 2017

https://en.wikipedia.org/wiki/Hoax, diakses Senin, 21 Agustus 2017

http://www.lpds.or.id/index.php?option=com_content\&view=article\&id=40:kode-etikjurnalistik\&catid=30:kode-etik-jurnalistik\&Itemid=32, diakses Senin, 21 Agustus 2017.

\section{E. Makalah}

Adi Prasetyo, Stanley. Kode Etik dan Persoalan Pers. Makalah disampaikan dalam Uji Kompetensi Jurnalis (UKJ) Aliansi Jurnalis Independen (AJI) Makassar, Hotel Remcy, 21 Juli 2017 